\title{
PENERAPAN MODEL PEMBELAJARAN THINK TALK WRITE TERHADAP KEMAMPUAN KOMUNIKASI MATEMATIS SISWA KELAS X IPA
}

\author{
Monika Retno Wulandari ${ }^{1}$, Aty Nurdiana ${ }^{2}$, Partono $^{3}$ \\ STKIP PGRI Bandar Lampung ${ }^{1,2,3}$ \\ aty_nurdiana@stkippgribdl.ac.id ${ }^{2}$,partonogapar@gmail.com ${ }^{3}$
}

\begin{abstract}
ABSTRAK
Permasalahan yang dikaji dalam penelitian berhubungan dengan rendahnya kemampuan komunikasi matematis siswa. Berdasarkan hal tersebut, penelitiannya bertujan untuk mengetahui pengaruh penerapan model pembelajaran Think Talk Write terhadap kemampuan komunikasi matematis siswa kelas X IPA semester genap SMA Negeri 3 Bandar Lampung tahun pelajaran 2018/2019. Metode yang digunakan adalah metode eksperimen yaitu dengan menerapkan langsung model pembelajaran Think Talk Write pada kelas eksperimen dan model pembelajaran konvensional pada kelas kontrol. Populasinya seluruh kelas X IPA semester genap yang tersebar dalam 4 kelas dengan jumlah keseluruhan 127 siswa. Teknik Cluster Random Sampling digunakan untuk mengambil kelas sampel dan didapat kelas X IPA 3 sebagai kelas eksperimen dan kelas X IPA 2 sebagai kelas kontrol dengan jumlah masing-masing 32 siswa. Pengumpulan data menggunakan teknik tes. Analisis data statistik menggunakan uji Wilcoxon. Berdasarkan hasil analisis uji Wilcoxon pada taraf $5 \%$ diperoleh $z_{\text {hitung }}<z_{\text {tabel }}(1,64<1,96)$. Dengan demikian, penerapan model pembelajaran Think Talk Write berpengaruh positif terhadap kemampuan komunikasi matematis siswa kelas X IPA semester genap SMA Negeri 3 Bandar Lampung tahun pelajaran 2018/2019.
\end{abstract}

Kata kunci : think talk write, komunikasi matematis

\begin{abstract}
The problem in this study is related to the low mathematical communication skills of students. Based on this problem, the research aims to find out the effect of the application of Think Talk Write learning model to the mathematical communication skills of students class X IPA in SMA Negeri 3 Bandar Lampung, in the even semester, academic year 2018/2019. The method used is an experimental method that is by applying the Think Talk Write learning model directly to the experimental class and the conventional learning model to the control class. The population is the entire class X IPA in even semester which is spread in 4 classes with a total of 127 students. Cluster Random Sampling technique is used to take the sample class and obtain class X IPA 3 as an experimental class and class X IPA 2 as a control class with a total of 32 students for each. Data were collected using test technique. Statistical data were analyzed using the Wilcoxon test. Based on the results of the analysis of the Wilcoxon test at a level of $5 \%$ was obtained $z_{\text {score }}<z_{\text {table }}(1,64<1,96)$. Thus, the application of the Think Talk Write learning model has a positive effect on
\end{abstract}


the mathematical communication skills of students of class X IPA in the even semester of SMA Negeri 3 Bandar Lampung in the academic year 2018/2019.

Keywords : think talk write, mathematical communication

\section{PENDAHULUAN}

Matematika merupakan mata pelajaran yang sangat penting dalam perkembangan ilmu pengetahuan, karena matematika melayani semua bidang ilmu khususnya dalam masalah pemodelan dan pengukuran, sehingga matematika mesti diajarkan mulai dari jenjang Sekolah Dasar sampai dengan Perguruan Tinggi.

National Countil of Teachers of Matematics (NCTM, 2000) menyatakan bahwa ada 5 (lima) kemampuan dasar yang harus dikuasai siswa, yang meliputi (1) pemecahan masalah; (2) penalaran dan bukti; (3) komunikasi; (4) koneksi; dan (5) representasi. Sejalan dengan pendapat tersebut, Pemerintah Indonesia melalui Peraturan Menteri Pendidikan dan Kebudayaan (Permendikbud) Nomor 21 Tahun 2016 yang tertuang dalam Standar Isi Pendidikan Dasar dan Menengah juga menetapkan salah satu kecakapan atau kemahiran matematika siswa dari SD/MI sampai SMA/MA yang diharapkan tercapai dalam belajar matematika yang di antaranya adalah memiliki kemampuan mengomunikasikan gagasan matematika dengan jelas dan efektif. Dengan demikian, kemampuan komunikasi matematika harus dimiliki oleh setiap siswa.

Melalui bekal komunikasi matematika yang baik tentunya pemahaman konsep matematika siswa akan lebih mendalam. Baik secara oral maupun tertulis, komunikasi matematika merupakan cara untuk berbagi gagasan dan memperjelas pemahaman. Melalui komunikasi matematika, gagasan matematika dapat digambarkan, diperbaiki, didiskusikan, dan dikembangkan.

Terlepas dari upaya yang dilaksanakan, masih saja ditemui permasalahan mengenai rendahnya kemampuan komunikasi matematis siswa akibat dari kebiasaan siswa yang hanya terpaku pada contoh soal yang diberikan oleh guru, mengosongkan jawaban pada lembar kerja, dan kesulitan menyampaikan pendapat dalam diskusi kelas. Berdasarkan pra penelitian, keadaan tersebut juga terjadi di SMA Negeri 3 Bandar Lampung hingga menyebabkan rendahnya kemampuan komunikasi matematis siswa pada kelas X IPA. Dari 5 soal tes berbentuk uraian yang diberikan menunjukkan bahwa dari 31 siswa yang ada hanya sekitar $16 \%$ atau 5 siswa yang mampu menyelesaikan soal kemampuan komunikasi matematis, artinya sisa sekitar $84 \%$ atau 26 siswa belum mampu menjawab soal tes kemampuan komunikasi matematis. Dengan kurang maksimalnya perolehan nilai ini, maka dapat dikatakan kemampuan komunikasi matematika siswa juga masih rendah.

Mengingat pentingnya kemampuan komunikasi matematis ini maka dalam merancang dan melaksanakan pembelajaran perlu untuk menyatakan pengembangan kemampuan komunikasi matematis siswa agar siswa terbiasa berargumen dan bekerja secara matematis dalam mengungkapkan pemikiran dan permasalahan matematikanya. Salah satu upayanya adalah dengan menerapkan model pembelajaran kooperatif tipe Think Talk Write (TTW) yang merupakan model pembelajaran yang memberikan kesempatan bagi siswa untuk membangun 
pemikiran, merefleksikan, dan mengorganisasi ide matematika, kemudian menguji ide tersebut sebelum siswa diharapkan untuk menuliskan ide-ide tersebut.

Model TTW diterapkan melalui tiga kemampuan matematis yakni berpikir matematis, berbicara matematis, dan menulis matematis. Berpikir matematis diterapkan dengan memahami suatu peristiwa atau masalah matematis. Kemampuan berbicara diterapkan saat siswa mengemukakan secara lisan berbagai ide matematis berdasarkan pengetahuannya. Selanjutnya, kemampuan menulis diterapkan dengan mengarahkan siswa untuk menuangkan ide matematis yang telah diperolehnya, dalam bentuk tulisan menggunakan bahasa matematis yakni simbol-simbol ataupun konsep dan aturan matematis. Dengan demikian, model TTW ini memiliki hubungan dengan kemampuan matematika (Isrok'atun dan Rosmala, 2018:154).

Menurut Iru (Bunga dkk, 2015 : 66) Think Talk Write merupakan model pembelajaran kooperatif yang mempunyai perencanaan cermat mengenai kegiatan pembelajaran, yaitu melalui kegiatan berpikir (think), berbicara atau berdiskusi, bertukar pendapat (talk), serta menuliskan hasil diskusi (write) agar tujuan pembelajaran dan kompetensi yang diharapkan dapat tercapai. Senada dengan Iru, Isrok'atun dan Rosmala (2018:154) yang menyatakan bahwa model TTW diterapkan melalui tiga kemampuan matematis yakni berpikir matematis, berbicara matematis, dan menulis matematis.

Kelebihan dari model pembelajaran Think Talk Write menurut Hamdayana (2014:222), yaitu (1) mempertajam seluruh keterampilan berpikir visual; (2) mengembangkan pemecahan yang bermakna dalam rangka memahami materi ajar; (3) dengan memberikan soal open ended, dapat mengembangkan berpikir kritis dan kreatif siswa; (4) dengan berinteraksi dan berdiskusi dengan kelompok akan melibatkan secara aktif dalam belajar; dan (5) membiasakan siswa berpikir dan berkomunikasi dangan teman, guru dan bahkan dengan diri mereka sendiri.

Selain ada kelebihannya, model pembelajaran Think Talk Write juga memiliki kekurangan menurut Hamdayana (2014:222), yaitu (1) ketika siswa bekerja sama dengan kelompok itu mudah kehilangan kemampuan dan kepercayaan karena didominasi oleh siswa yang mampu; dan (2) guru harus benar-benar menyiapkan semua media dengan matang agar dalam menerapkan strategi Think Talk Write tidak mengalami kesulitan.

Lestari dan Yudhanegara (2017:83) berpendapat bahwa kemampuan komunikasi matematis adalah kemampuan menyampaikan gagasan/ide matematis, baik secara lisan maupun tulisan serta kemampuan memahami dan menerima gagasan/ ide matematis orang lain secara cermat, analitis, kritis, dan evaluatif untuk mempertajam pemahaman. Selain itu, Depdiknas (Fadilla, 2017:1) menyatakan bahwa salah satu tujuan pembelajaran matematika adalah mengomunikasikan gagasan dengan simbol, tabel, diagram, atau media lain untuk memperjelas keadaan atau masalah.

Kemudian, menurut Nari (2015:154-155) indikator kemampuan komunikasi matematis, yaitu (1) kemampuan menghubungkan benda nyata, gambar, dan diagram ke dalam ide matematika; (2) kemampuan menjelaskan ide, situasi, dan relasi matematika secara tulisan; (3) kemampuan menyatakan peristiwa atau ide dalam bahasa atau simbol matematika.

Penelitian seperti ini pernah dilakukan oleh Fadilla (2017) yang menyimpulkan bahwa terdapat pengaruh positif pembelajaran kooperatif tipe Think Talk Write terhadap kemampuan komunikasi matematis siswa Kelas VII SMP Swasta Nusantara 
Lubuk Pakam pada Materi Bangun Datar Segi Empat. Untuk mempertegas penelitian yang pernah dilakukan tersebut, perlu dilakukan kembali penelitian di tempat lain, apakah akan menghasilkan kesimpulan yang sama.

Dengan demikian, penelitian ini bertujuan untuk mengetahui pengaruh penerapan model pembelajaran Think Talk Write terhadap kemampuan komunikasi matematis siswa kelas X IPA semester genap SMA Negeri 3 Bandar Lampung tahun pelajaran 2018/2019.

\section{METODE}

Metode penelitian yang digunakan berupa eksperimen dengan dua kelompok. Kelas eksperimen menerapkan model pembelajaran Think Talk Write, sedangkan kelas kontrol menerapkan model konvensional. Variabel dalam penelitian ini terdiri dari model pembelajaran Think Talk Write dan kemampuan komunikasi matematis.

Penelitian ini dilaksanakan di SMA Negeri 3 Bandar Lampung pada semester genap tahun pelajaran 2018/2019 pada materi trigonometri. Populasinya adalah siswa kelas X IPA dengan total populasi 127 siswa yang tersebar dalam 4 kelas, yaitu X IPA 1, X IPA 2, X IPA 3, dan X IPA 4. Dalam penelitian ini kelas X IPA 3 dan X IPA 2 dipilih sebagai kelas eksperimen dan kelas kontrol.

Digunakan teknik Cluster Random Sampling dengan prosedur undian dalam menentukan sampel. Cara menentukannya adalah dengan mengundi 4 kelas untuk diambil 2 kelas yang dianggap mewakili kelompok tersebut, selanjutnya kedua kelas tersebut diundi lagi yang pertama keluar sebagai kelas eksperimen dan kelas yang kedua sebagai kelas kontrol. Teknik ini dilakukan karena mengingat kelas X IPA SMA Negeri 3 Bandar Lampung mempunyai kemampuan yang sama.

Teknik pengumpulan data yang digunakan adalah teknik tes. Adapun kemampuan komunikasi matematis siswa dalam penelitian ini akan diukur dengan tes uraian yang terdiri dari 5 soal pada materi trigonometri. Dalam penyusunan tes kemampuan komunikasi matematis diawali dengan menyusun kisi-kisi penelitian berdasarkan indikator kemampuan komunikasi matematis.

Untuk mempermudah dalam proses pemberian skor hasil pekerjaan siswa, digunakan skor tiap butir soal dengan aturan rubrik penskoran, kemudian skor siswa yang diperoleh dikonversi dalam interval $0 \leq x \leq 100$ dan menjadi data-data penelitian. Berikut adalah indikator dan rubrik penskoran menurut Nari (2015:154$155)$.

Tabel 1. Indikator dan rubrik penskoran kemampuan komunikasi matematika

\begin{tabular}{|c|c|c|}
\hline Indikator & Respon & Skor \\
\hline \multirow{5}{*}{$\begin{array}{l}\text { Memadukan benda } \\
\text { nyata, gambar, dan } \\
\text { diagram ke dalam ide } \\
\text { matematika. }\end{array}$} & $\begin{array}{l}\text { Jawaban benar, mampu menghubungkan } \\
\text { benda nyata, gambar, dan diagram ke } \\
\text { dalam ide matematika. }\end{array}$ & 4 \\
\hline & $\begin{array}{l}\text { Jawaban benar, sesuai dengan kriteria } \\
\text { tetapi ada sedikit jawaban yang salah. }\end{array}$ & 3 \\
\hline & $\begin{array}{l}\text { Jawaban benar tetapi tidak sesuai dengan } \\
\text { sebagian besar kriteria. }\end{array}$ & 2 \\
\hline & $\begin{array}{l}\text { Jawaban ada namun sama sekali tidak } \\
\text { sesuai dengan kriteria. }\end{array}$ & 1 \\
\hline & Jawaban tidak ada. & 0 \\
\hline
\end{tabular}




\begin{tabular}{|c|c|c|c|}
\hline \multirow[t]{5}{*}{2.} & \multirow{5}{*}{$\begin{array}{lr}\text { Menguraikan } & \text { ide, } \\
\text { situasi, dan } & \text { relasi } \\
\text { matematik } & \text { secara } \\
\text { tulisan. } & \end{array}$} & $\begin{array}{l}\text { Jawaban benar, mampu menghubungkan } \\
\text { benda nyata, gambar, dan diagram ke } \\
\text { dalam ide matematika. }\end{array}$ & 4 \\
\hline & & $\begin{array}{l}\text { Jawaban benar, sesuai dengan kri-eria } \\
\text { tetapi ada sedikit jawaban yang salah. }\end{array}$ & 3 \\
\hline & & $\begin{array}{l}\text { Jawaban benar tetapi tidak sesuai dengan } \\
\text { sebagian besar kriteria. }\end{array}$ & 2 \\
\hline & & $\begin{array}{l}\text { Jawaban ada namun sama sekali tidak } \\
\text { sesuai dengan kriteria. }\end{array}$ & 1 \\
\hline & & Jawaban tidak ada. & 0 \\
\hline 3. & \multirow{6}{*}{$\begin{array}{l}\text { Mengemukakan } \\
\text { peristiwa atau ide dalam } \\
\text { bahasa atau simbol } \\
\text { matematika. }\end{array}$} & $\begin{array}{l}\text { Jawaban benar, mampu menghubungkan } \\
\text { benda nyata, gambar, dan diagram ke } \\
\text { dalam ide matematika. }\end{array}$ & 4 \\
\hline & & $\begin{array}{l}\text { Jawaban benar, sesuai dengan kriteria } \\
\text { tetapi ada sedikit jawaban yang salah. }\end{array}$ & 3 \\
\hline & & $\begin{array}{l}\text { Jawaban benar tetapi tidak sesuai dengan } \\
\text { sebagian besar kriteria. }\end{array}$ & 2 \\
\hline & & $\begin{array}{l}\text { Jawaban ada namun sama sekali tidak } \\
\text { sesuai dengan kriteria. }\end{array}$ & 1 \\
\hline & & Jawaban tidak ada. & 0 \\
\hline & & Skor maksimum & 12 \\
\hline
\end{tabular}

Sebelum digunakan dalam penelitian, instrumen tes kemampuan komunikasi matematika divalidasi dengan menggunakan rumus korelasi Product Moment (Arikunto, 2013:87) dan dihitung reliabilitasnya menggunakan rumus Alpha Cronbach (Siregar, 2013:58). Kemudian 5 soal yang telah valid dan reliabel tersebut digunakan untuk mendapatkan data mengenai kemampuan komunikasi matematis yang bertujuan untuk menguji kebenaran hipotesis.

Teknik analisis data yang digunakan dalam penelitian ini adalah sebagai berikut: (1) menentukan rata-rata skor dan simpangan baku, (2) uji normalitas, (3) uji homogenitas, dan (4) uji hipotesis. Dengan taraf nyata $(\alpha)=5 \%$, uji normalitas yang digunakan adalah $\chi^{2}$ dan uji homogenitas yang digunakan adalah uji kesamaan dua varians. Sedangkan untuk uji hipotesis dalam taraf nyata $(\alpha)=5 \%$ adalah $t_{\text {test }}$ untuk data normal dan homogen (Sudjana, 2005:239), $t^{\prime}$ untuk data normal tapi tidak homogen (Sudjana, 2005:227), dan uji Wilcoxon untuk data tidak normal dan homogen (Kustituanto, 2018:244-245).

\section{HASIL DAN PEMBAHASAN}

Penelitian ini dilaksanakan pada tanggal 9 April sampai dengan 10 Mei 2019 atau pada semester genap tahun pelajaran 2018/2019 di kelas X IPA SMA Negeri 3 Bandar Lampung dengan menggunakan dua kelas sebagai sampel. Kelas X IPA 3 sebagai kelas eksperimen yang diterapkan model pembelajaran Think Talk Write dan kelas X IPA 2 sebagai kelas kontrol yang diterapkan model pembelajaran konvensional, dengan jumlah siswa masing-masing 32 siswa.

Dalam pelaksanaan penelitian ini, siswa di kelas eksperimen dibagi menjadi beberapa kelompok dan diberi lembar kerja peserta didik (LKPD) yang di dalamnya terdapat masalah yang perlu diselesaikan dengan berdiskusi (berkomunikasi) 
bersama teman sekelompoknya. Namun, sebelumnya siswa terlebih dahulu dijelaskan bagaimana langkah-langkah model pembelajaran Think Talk Write.

Pada pertemuan pertama, siswa belum terbiasa menerapkan model pembelajaran Think Talk Write sehingga kondisi di kelas kurang kondusif. Siswa masih belum paham dalam menerapkan langkah-langkah model pembelajaran Think Talk Write. Pada pertemuan kedua, kondisi di kelas masih perlu dikondusifkan dan siswa diingatkan kembali mengenai langkah-langkah model pembelajaran Think Talk Write. Kemudian, pada pertemuan ketiga, siswa mulai terbiasa menerapkan model pembelajaran Think Talk Write sehingga pembelajaran mulai kondusif. Siswa menghadapi masalah dengan berpikir (think) secara individu terlebih dahulu, kemudian siswa akan mulai berkomunikasi (talk) dengan teman sekelompoknya guna menyelesaikan masalah yang diberikan oleh guru, dan setelah mendapatkan penyelesaian siswa menuliskan (write) gagasannya pada LKPD. Penarikan kesimpulan masalah dilakukan dengan presentasi kelas. Pada pertemuan selanjutnya, pembelajaran mulai aktif dan terlihat kerja sama yang baik antaranggota kelompok.

Berdasarkan pada observasi terhadap komunikasi matematis siswa di kelas ekperimen didapatkan siswa mempunyai rasa ingin tahu yang kuat sehingga membuatnya aktif dan antusias dalam berpikir individu (think). Pada keadaankeadaan tertentu didapati siswa-siswa yang pintar lebih suka belajar sendiri maka siswa diajak berdiskusi agar suasana kelas lebih menyenangkan dan terjadi interaksi antar siswa dalam kelas baik berupa bertanya maupun menjawab pertanyaan dalam diskusi kelas (talk). Kemudian meninjau pada observasi pada lembar kerja peserta didik (LKPD) dan lembar kerja tes kemampuan komunikasi siswa, didapati sebagian besar siswa mampu menjawab soal-soal yang berhubungan dengan indikator kemampuan komunikasi matematika (write).

Berbeda dengan kelas eksperimen, kelas kontrol tidak diterapkan model pembelajaran Think Talk Write pada proses pembelajarannya. Kegiatan belajar berlangsung sesuai kurikulum yang diterapkan di sekolah tersebut. Pembelajaran di kelas kontrol diterapkan model konvensional. Pada setiap pertemuannya belum sepenuhnya terpusat pada siswa, guru masih sering berperan aktif dalam menyajikan materi di dalam kelas, sehingga siswa kurang merespon seluruh kegiatan belajar dan hanya beberapa yang semangat dalam pembelajaran dan mengerjakan soal latihan. Akibat yang ditimbulkan adalah kurangnya pengetahuan siswa dalam kemampuan komunikasi matematis.

Berdasarkan pada observasi terhadap kemampuan komunikasi matematis siswa di kelas konvensional yang diterapkan model pembelajaran konvensional didapatkan keadaan dimana belum banyak siswa yang berminat untuk menikmati pembelajaran mulai dari siswa yang menguap maupun melihat ke luar kelas hingga mengakibatkan proses belajar mengajar terhambat. Kemudian, ditinjau dari hasil observasi pada lembar kerja peserta didik (LKPD) dan lembar kerja tes kemampuan komunikasi siswa, didapati bahwa banyak siswa yang belum mencapai indikator kemampuan komunikasi matematika. 
Tabel 2. Sebaran data kemampuan komunikasi matematis siswa

\begin{tabular}{lcc}
\hline \multicolumn{1}{c}{ Sebaran data } & Kelas eksperimen & Kelas kontrol \\
\hline Minimal & 68 & 66 \\
\hline Maksimal & 95 & 95 \\
\hline Mean & 85,03 & 83,31 \\
\hline Median & 87,5 & 86,06 \\
\hline Modus & 91,75 & 89,07 \\
\hline Standar deviasi & 7,92 & 9,06 \\
\hline Jumlah siswa & 32 & 32 \\
\hline
\end{tabular}

Berdasarkan sebaran data yang didapatkan setelah dilakukan tes dengan 5 soal uraian, diperoleh data seperti yang ada di tabel 2 di atas untuk masing-masing kelas. Sebagaimana terlihat dalam tabel 2 di atas menunjukkan adanya perbedaan hasil tes kemampuan komunikasi matematis siswa yang menggunakan model pembelajaran Think Talk Write dengan siswa yang menggunakan model pembelajaran konvensional.

Kemampuan komunikasi matematis merupakan hasil belajar yang umumnya memiliki klasifikasi skor $\leq 50$ termasuk kategori sangat kurang, skor $50-55$ dalam kategori kurang, skor 56-65 kategori cukup, skor 66- 75 termasuk kategori baik, dan skor $\geq 76$ dalam kategori sangat baik.

Kemampuan komunikasi matematis siswa yang diajarkan dengan model pembelajaran Think Talk Write menunjukkan rata-rata nilai di atas KKM yang telah ditetapkan. Hal ini dapat dilihat dari nilai rata-rata sebesar 85,03 berada di atas nilai KKM matematika sebesar 72. Sementara jika mengacu kepada standar kategori yang lazim digunakan, nilai rata-rata tersebut berada pada interval $\geq 80$ yang artinya berada pada rentangan yang sangat baik. Artinya tingkat kemampuan komunikasi matematis para siswa kelas X IPA 3 SMA Negeri 3 Bandar Lampung rata-rata sudah pada kategori baik.

Kemampuan komunikasi matematis siswa yang diajarkan dengan model pembelajaran konvensional juga menunjukkan rata-rata siswa memperoleh nilai di atas KKM yang telah ditetapkan. Hal ini dapat dilihat dari nilai rata-rata sebesar 83,31 berada di atas nilai KKM matematika sebesar 72. Sementara jika mengacu kepada standar kategori yang lazim digunakan, nilai rata-rata tersebut berada pada interval $\geq 80$ yang artinya berada pada rentangan yang sangat baik juga. Artinya tingkat kemampuan komunikasi matematis para siswa kelas X IPA 2 SMA Negeri 3 Bandar Lampung rata-rata sudah pada kategori baik juga.

Data-data tersebut di atas, akan digunakan untuk analisis. Sebelum pengujian hipotesis, terlebih dahulu dilakukan uji prasyarat yang meliputi uji normalitas data dan uji homogenitas varians. Hasil ini dipergunakan untuk menentukan rumus uji kesamaan rata-rata mana yang akan dipakai.

Pengujian normalitas data dilakukan dengan menggunakan uji Chi kuadrat pada taraf nyata $(\alpha)=5 \%$ dengan Ho : sampel berasal dari populasi yang memiliki distribusi normal dan $\mathrm{Ha}$ : sampel berasal dari populasi yang berdistribusi tidak normal. 
Tabel 3. Uji normalitas kelas eksperimen dan kelas kontrol

\begin{tabular}{lccc}
\hline \multicolumn{1}{c}{ Kelas } & $\chi_{\text {hitung }}^{2}$ & $\chi_{\text {tabel }}^{2}$ & Keterangan \\
\hline Eksperimen & 11,42 & 7,81 & Tidak normal \\
\hline Kontrol & 19,43 & 7,81 & Tidak normal \\
\hline
\end{tabular}

Berdasarkan hasil perhitungan uji normalitas dengan menggunakan rumus $C h i$ kuadrat pada taraf nyata $(\alpha)=5 \%$ didapat $\chi_{\text {tabel }}^{2}=7,81$. Kemudian, untuk kelas eksperimen $\chi_{\text {hitung }}^{2}=11,42$ dan kelas kontrol $\chi_{\text {hitung }}^{2}=19,43$. Berdasarkan kriteria uji, tolak Ho karena $\chi_{\text {hitung }}^{2} \geq \chi_{\text {tabel }}^{2}$. Dengan demikian dapat disimpulkan bahwa kedua sampel berdistribusi tidak normal.

Selanjutnya, data akan diuji homogenitas variansnya dengan Ho : kedua sampel memiliki varians yang sama dan Ha : kedua sampel tidak memiliki varians yang sama.

Tabel 4. Uji homogenitas varians kelas eksperimen dan kelas kontrol

\begin{tabular}{lcccc}
\hline \multicolumn{1}{c}{ Kelas } & $\mathrm{n}$ & $F_{\text {hitung }}$ & $F_{\text {tabel }}$ & Keterangan \\
\cline { 1 - 2 } Eksperimen & 32 & \multirow{2}{*}{1,40} & 1,84 & Homogen \\
\cline { 1 - 2 } Kontrol & 32 & & & \\
\hline
\end{tabular}

Berdasarkan data, pada taraf nyata $(\alpha)=5 \%$ diperoleh $F_{\text {tabel }}=1,84$ dan diperoleh $F_{\text {hitung }}=1,40$. Berdasarkan kriteria uji, tolak Ho jika $F_{\text {hitung }}>F_{\text {tabel }}$. Dengan demikian, dapat dilihat bahwa Ho diterima atau dapat disimpulkan kedua data mempunyai varians yang sama.

Berdasarkan uji prasyarat didapatkan kedua data tidak normal namun variansnya homogen maka pengujian hipotesis yang diajukan menggunakan uji Wilcoxon (uji bertanda). Hipotesis penelitian adalah rata-rata kemampuan komunikasi matematis siswa yang diterapkan model pembelajaran Think Talk Write (TTW) tidak sama dengan kemampuan komunikasi matematis siswa yang diterapkan pembelajaran konvensional, dengan Ho : rata-rata kelas eksperimen sama dengan rata-rata kelas kontrol dan $\mathrm{Ha}$ : rata-rata kelas eksperimen tidak sama dengan ratarata kelas kontrol.

Tabel 5. Uji hipotesis kesamaan dua rata-rata

\begin{tabular}{|c|c|c|c|c|c|c|}
\hline \multicolumn{2}{|c|}{ Tanda rank } & $\mu_{T}$ & $\sigma_{T}$ & $z_{\text {hitung }}$ & $z_{\text {tabel }}$ & Keterangan \\
\cline { 1 - 5 }+ & 351,5 & \multirow{2}{*}{264} & 53,48 & 1,64 & 1,96 & Tidak sama \\
\hline- & 176,5 & &
\end{tabular}

Dari hasil perhitungan uji kesamaan dua rata-rata menggunakan uji Wilcoxon pada taraf nyata $(\alpha)=5 \%$ diperoleh $z_{\text {tabel }}=1,96$ dan $z_{\text {hitung }}=1,64$. Berdasarkan kriteria uji tolak Ho jika $z_{\text {hitung }}<z_{\text {tabel }}$. Dengan demikian, rata-rata kemampuan komunikasi matematis siswa yang diterapkan pembelajaran Think Talk Write tidak sama dengan rata-rata kemampuan komunikasi matematis siswa yang diterapkan pembelajaran konvensional. 
Berdasarkan hasil penelitian di atas, terlihat bahwa kegiatan belajar siswa yang menggunakan model pembelajaran Think Talk Write menghasilkan kemampuan komunikasi matematika siswa yang lebih baik dibandingkan dengan siswa yang diterapkan pembelajaran konvensional. Berdasarkan perhitungan yang telah diperoleh yaitu adanya pengaruh penerapan model pembelajaran Think Talk Write terhadap kemampuan komunikasi matematis siswa kelas X IPA SMA Negeri 3 Bandar Lampung tahun pelajaran 2018/2019.

Dengan demikian, dari hasil penelitian yang telah dilaksanakan, dapat diambil kesimpulan umum bahwa model pembelajaran Think Talk Write berpengaruh terhadap rata-rata kemampuan komunikasi matematis siswa, sehingga akan lebih baik apabila pada proses pembelajarannya guru menggunakan model pembelajaran Think Talk Write.

\section{SIMPULAN DAN SARAN}

Berdasarkan hasil analisis data yang telah dilakukan dapat disimpulkan bahwa: "Ada pengaruh penerapan model pembelajaran Think Talk Write terhadap kemampuan komunikasi matematis siswa kelas X IPA SMA Negeri 3 Bandar Lampung tahun pelajaran 2018/2019" dengan rata-rata kemampuan komunikasi matematis siswa yang menggunakan model pembelajaran Think Talk Write lebih tinggi dari rata-rata kemampuan komunikasi matematis siswa yang menggunakan pembelajaran konvensional.

Disarankan kepada guru atau tenaga pendidik agar menerapkan model pembelajaran Think Talk Write untuk memperbaiki dan/atau meningkatkan kemampuan komunikasi matematis siswa.

\section{DAFTAR PUSTAKA}

Arikunto, S. 2013. Dasar-Dasar Evaluasi Pendidikan. Jakarta: Bumi Aksara.

Bunga, Thahar, H.E., dan Juita, N. 2015. Pengaruh Model Pembelajaran Kooperatif dengan Strategi Think Talk Write dan Motivasi Belajar Terhadap Hasil Belajar Menulis Naskah Drama Siswa Kelas VIII SMP Negeri 3 Batang Anai. Jurnal Bahasa, Sastra, dan Pembelajaran, Vol. 2 (1) : 63-74. [Online]. Tersedia : http://ejournal.unp.ac.id/index.php/bsp/article/view/4984.

Fadilla, Fitri Y. 2017. Peningkatan Kemampuan Komunikasi Matematik Siswa yang Menggunakan Model Pembelajaran Koperatif Tipe Think-Thalk-Write pada Materi Bangun Datar Segi Empat Kelas VII SMP Swasta Nusantara Lubuk Pakam. Makalah Pada Prosiding Seminar Nasional Matematika (SEMNASTIKA) Fakultas Matematika Universitas Negeri Medan, Medan, 6 Mei 2017. ISBN : 978-602-17980-9-6.

Hamdayana, J. 2014. Model dan Metode Pembelajaran Kreatif dan Berkarakter. Bogor: Ghalia Indonesia.

Isro'atun dan Rosmala, Amelia. 2018. Model-Model Pembelajaran Matematika. Bandung: PT Bumi Aksara.

Kustituanto, Bambang. 2018. Statistika untuk Ekonomi dan Bisnis. Yogyakarta: Andi dan BPFE.

Lestari, K.E. dan Yudhanegara, M.R. 2017. Penelitian Pendidikan Matematika. Bandung: PT Refika Aditama. 
Nari, Nola. 2015. Kemampuan Komunikasi dan Disposisi Matematis Mahasiswa pada Mata Kuliah Geometri. Jurnal Ta'dib, Vol. 18 (2) : 150-162.

NCTM. 2000. Curriculum and Evaluation Standards for School Mathematics. Reston, VA: NCTM.

Peraturan Menteri Pendidikan dan Kebudayaan No. 21 Tahun 2016 Tentang Standar Isi Pendidikan Dasar dan Menengah. [Online]. Tersedia: http://vervalsp.data.kemdikbud.go.id/prosespembelajaran/file/Permendikbud_T ahun2016_Nomor022_Lampiran.pdf. [November 2018].

Siregar, Syofian. 2013. Metode Penelitian Kuantitatif. Jakarta: PT. Fajar Interpratama Mandiri.

Sudjana. 2005. Metoda Statistika. Bandung: Tarsito. 